\title{
Impact of FDI, COP, and Inflation to Export in Five Asean Countries
}

\author{
Nanda Adhi Purusa ${ }^{1 *}$, Nurul Istiqomah ${ }^{2)}$ \\ ${ }^{12}$ Departement of Economic Development, Faculty of Economic and Business \\ Universitas Sebelas Maret, Surakarta, Indonesia \\ *Corresponding Author: nandapurusa@gmail.com
}

Recieved March 2018 | Revised April 2018 | Accepted July 2018

\begin{abstract}
The effects of foreign direct investment (FDI), crude oil price and inflation on the export are mainly examined in the case of Indonesia, Malaysia, Philippines, Thailand, and Vietnam by using data from 2000 to 2015. These countries have opportunity to increased prosperity in the ASEAN Economic Community (AEC). Therefore, increasing productivity and international trading are important for each country. This study employed panel data model in the analyses and the findings show that Fixed Effect Model with Generalized Least Square method is implemented. Hence, using this method is determined by likelihood test and Hausman test. The statistical tests in this study consist of partial coefficient test, stimulant, and coefficient of determination. The result shows that FDI and crude oil price have positive effect and significant on export, but inflation has negative effect and significant on export. Constant value shows that each country has the difference condition. Simple bureaucracy is needed to increased efficiency that will attract foreign investors to invest their fund and the discovery of alternative energy and new production technique can increase a country productivity significantly in producing goods or services for both domestic and export-oriented.
\end{abstract}

Keywords: FDI, Crude Oil Price, Inflation, Export, ASEAN

JEL classification: F21, E31, B27

How to Cite: Purusa, N., \& Istiqomah, N. (2018). Impact of FDI, COP, and Inflation to Export in Five ASEAN Countries. Jurnal Ekonomi Pembangunan: Kajian Masalah Ekonomi dan Pembangunan, 19(1), 94-101. doi:https://doi.org/10.23917/jep.v19i1.5832

DOI: https://doi.org/10.23917/jep.v19i1.5832

\section{Introduction}

The Asean Economic Community (AEC) enacted in early 2016, becomes an important moment for all countries in Southeast Asia region, particularly ASEAN countries. Trade is the key to supporting domestic industry and economic growth. Low production cost, good facilities and infrastructure, and human resource skills is the requirements that must be met for all ASEAN countries to compete within the AEC, which implements free trade policy (without tariffs) in the region.
Kabir (2014) shows that the export intensity on 2011 to 2012 in Indonesia, Malaysia, Philippines, Thailand, Singapore, and Vietnam are only slightly decreased. This is the impact of the 2008 Global Financial Crisis. The export intensity represents the amount or volume of exports that transacted every year for each dollar of GDP. Cooperation with East Asian countries (China, Japan, and Korea) has increased the export of ASEAN countries, and more than onefifth of ASEAN's total exports flows to three East Asian countries in recent years. Pardede (2011) 
also states that ASEAN has a strong political influence and an important role in international trade. From January to August 2010, ASEAN countries have an export value of 17.293 billion US Dollar, which is bigger than EU, China, and United States.

The AEC integration will enhance ASEAN countries' attraction for foreign investors in the form of Foreign Direct Investment (FDI) and provide opportunities to minimize production cost, support technology transfer, and create efficiency that increases export. In addition, FDI also increases competitiveness in industry and business, which is an important factor to encourage export of a country. Thus, ASEAN countries will not only export raw materials to manufacturing industries overseas but also capable to process the material into finished goods that have more value and can intensify the real sector (Pardede, 2011).

Romer in Karsalari et al (2013) states that FDI plays an important role in supporting export performance through increased productivity and production capacity in a country by increasing capital, technology transfer, managerial skills, and enhance local worker skills. Thus, FDI can also provide an opportunity for a country to expand its export market access. This is in line with a research conducted by Dritsaki (2012: 3136) in EU countries in the period of 1995-2010, which indicates that FDI has a positive and significant effect on export volume in the long term. Furthermore, a research by Lutz (2004) in the Ukraine, in four different regions, namely Kyiv, Kharkiv, Odesa, and Lviv, indicates that foreign direct investment has a positive effect on labor productivity and export volume.

Increasing a country productivity cannot be separated from the availability of production factors of the goods and services produced. This is related to the commodity price fluctuations that has an important role in goods and services production. Crude oil is claimed to be one of the most important commodities in the world
(Hubbard in Ekmekcioglu, 2012). They observed that crude oil prices are heavily affected by its supply and demand. Crude oil has changed the business scenario and generates tremendous economic growth for oil-exporting countries. Crude oil has an important role and many advantages related to the world's products. It is related to the production of a good or service for domestic needs as well as for export matters. Thus, crude oil price fluctuations can affect a country export growth.

Given its vital role, the implications of crude oil price fluctuations are varied. Studies conducted after the crude oil shocks in the 1970s have seen as justification fundamental that crude oil crisis is the cause of the economic recession, especially in the United States and some European countries at that time. Other empirical studies are conducted to examine the mechanism of oil shocks effect on the economy, ranging from the demand effect, supply, and even effect on trade of goods and services (Hamilton in Nizar, 2012).

The increase in demand for processed products from crude oil and the rise in demand for the crude oil has caused oil prices to continue to fluctuate and caused uncertainty. Countries that have a natural resource of crude oil have experienced an exceptional economic growth because of the large profits from crude oil trading. The increase in crude oil prices, pushing a shift in market scenarios across countries that are constantly looking for an efficient and appropriate alternative energy for crude oil substitutes and to meet the needs of goods and services production especially in a country's export production (Hooker in Ekmekcioglu, 2012).

The novelty of this research is to know the implications of FDI, crude oil price and inflation to the export of ASEAN countries especially Indonesian, Malaysia, Philippines, Thailand and Vietnam. Based on previous research, there are only explain about the relationship between FDI and crude oil price to export. While the impact of inflation to export is needs to be studied more deeply. 
Avalaible online at http://journals.ums.ac.id, Permalink/DOI: 10.23917/jep.v19i1.5832

Jurnal Ekonomi Pembangunan: Kajian Masalah Ekonomi dan Pembangunan, 19 (1), 2018, 94-101

Table 1. Likelihood Test Result

\begin{tabular}{cccc}
\hline Effect Test & Statistic & d.f. & Prob \\
\hline Cross-section F & 34.852803 & $(4.72)$ & 0.0000 \\
Cross-section F Chi-square & 86.171119 & 4 & 0.0000 \\
\hline
\end{tabular}

Source: Processed by Eviews 8

Table 2. Hausman Test Result

\begin{tabular}{cccc}
\hline Test Summary & Chi-Sq Statistic & Chi-Sq d.f. & Prob \\
\hline Cross-section random & 95.792163 & 3 & 0.0000 \\
\hline \multicolumn{4}{c}{ Source: Processed by Eviews 8 }
\end{tabular}

Table 3. Result of Panel Data

\begin{tabular}{|c|c|c|c|c|}
\hline \multicolumn{5}{|c|}{ Result of Pooled Least Square } \\
\hline Variables & Coefficient & Std.Error & t-Statistic & Prob. \\
\hline FDI & 6.213953 & 1.160825 & 5.353047 & 0.0000 \\
\hline $\mathrm{COP}$ & $1.71 \mathrm{E}+09$ & $1.86 \mathrm{E}+08$ & 9.191093 & 0.0000 \\
\hline INF & $-5.95 \mathrm{E}+09$ & $1.45 \mathrm{E}+09$ & -4.096210 & 0.0001 \\
\hline R-squared & 0.589509 & \multicolumn{2}{|c|}{ Mean dependent var } & $1.28 \mathrm{E}+11$ \\
\hline Adjusted R-squared & 0.578846 & \multicolumn{2}{|c|}{ S.D. dependent var } & $7.73 \mathrm{E}+10$ \\
\hline S.E. of regression & $5.02 \mathrm{E}+10$ & \multicolumn{2}{|c|}{ Durbin-Watson stat } & 0.347312 \\
\hline Sum squared resid & $1.94 \mathrm{E}+23$ & & & \\
\hline \multicolumn{5}{|c|}{ Result of Fixed Effect Model } \\
\hline Variables & Coefficient & Std.Error & t-Statistic & Prob. \\
\hline $\mathrm{C}$ & $3.64 \mathrm{E}+10$ & $8.50 \mathrm{E}+09$ & 4.286680 & 0.0001 \\
\hline FDI & 3.651777 & 0.776682 & 4.701769 & 0.0000 \\
\hline $\mathrm{COP}$ & $1.34 \mathrm{E}+09$ & $1.64 \mathrm{E}+08$ & 8.160930 & 0.0000 \\
\hline INF & $-3.77 \mathrm{E}+09$ & $1.06 \mathrm{E}+09$ & -3.565008 & 0.0007 \\
\hline $\mathrm{R}$-squared & 0.878034 & \multicolumn{2}{|c|}{ Mean dependent var } & $1.28 \mathrm{E}+11$ \\
\hline Adjusted R-squared & 0.866177 & \multicolumn{2}{|c|}{ S.D. dependent var } & $7.73 \mathrm{E}+10$ \\
\hline S.E. of regression & $2.83 \mathrm{E}+10$ & \multicolumn{2}{|c|}{ Sum squared resid } & $5.81 \mathrm{E}+22$ \\
\hline F-statistic & 74.04717 & \multicolumn{2}{|c|}{ Durbin-Watson stat } & 0.499690 \\
\hline Prob (F-statistic) & 0.000000 & & & \\
\hline \multicolumn{5}{|c|}{ Result of Random Effect Model } \\
\hline Variables & Coefficient & Std.Error & t-Statistic & Prob. \\
\hline $\mathrm{C}$ & $4.38 \mathrm{E}+10$ & $8.75 \mathrm{E}+09$ & 5.002694 & 0.0000 \\
\hline FDI & 5.633923 & 0.690615 & 8.157833 & 0.0000 \\
\hline $\mathrm{COP}$ & $1.19 \mathrm{E}+09$ & $1.53 \mathrm{E}+08$ & 7.738791 & 0.0000 \\
\hline INF & $-5.98 \mathrm{E}+09$ & $8.95 \mathrm{E}+08$ & -6.686029 & 0.0000 \\
\hline R-squared & 0.654387 & \multicolumn{2}{|c|}{ Mean dependent var } & $1.03 \mathrm{E}+11$ \\
\hline Adjusted R-squared & 0.640744 & \multicolumn{2}{|c|}{ S.D. dependent var } & $7.05 \mathrm{E}+10$ \\
\hline S.E. of regression & $4.23 \mathrm{E}+10$ & \multicolumn{2}{|c|}{ Sum squared resid } & $1.36 \mathrm{E}+23$ \\
\hline F-statistic & 47.96636 & \multicolumn{2}{|c|}{ Durbin-Watson stat } & 0.373075 \\
\hline Prob (F-statistic) & 0.000000 & & & \\
\hline
\end{tabular}




\section{Research Method}

The scope of this study is covering an open economy or international economy that includes the five countries incorporated in the Asociation of South East Asian Nation (ASEAN), namely Indonesia, Malaysia, Philippines, Thailand, and Vietnam. The type of data used in this study is secondary data using export volume, FDI, crude oil price, and inflation for the year of 2000-2015. This study uses panel data analysis, which is a combination of time-series data during 20002015 and cross-section data covering the five countries. The panel data in this research is a balanced panel data, since each subject (country) has the same number of observations (Gujarati, 2012). A common panel data regression model looks like:

$$
\begin{array}{ll}
\log Y_{i}=\beta_{0} & +\beta_{1} \log \operatorname{Exp}_{i}+\sum \alpha_{i} \log X_{i}+u_{i} \\
\mathrm{X} & =\text { Export } \\
\mathrm{FDI} & =\text { Foreign Direct Invesment } \\
\mathrm{COP} & =\text { Crude oil Price } \\
\mathrm{Inf} & =\text { Inflation } \\
\mathrm{B} 0 & =\text { intercept } \\
\beta_{1}, \beta_{2}, \beta_{3} & =\text { coefficients } \\
\mu & =\text { error correction term } \\
\mathrm{i} & =\text { indices for individuals } \\
\mathrm{t} & =\text { indices for time }
\end{array}
$$

\section{Results And Discussion 3.1. Results}

The determination of the method to be used in panel data analysis in this study should be done through several tests. The methods available are Pooled Least Square (PLS), Fixed Effect, or Random Effect method. The likelihood and the Hausman test are the finest way to determine which model is best used in the analysis.
Likelihood test result presented in Table 1, shows that the result is significant at 5 percent significance level, the value of f-statistic is $34.852803>\mathrm{F}$-table is 2.80 or $\mathrm{p}$-value is 0.0000 $<0.05$. This mean that the $\mathrm{HO}$ is rejected and $\mathrm{H} 1$ accepted, thus the model use Fixed Effect Model. Therefore, Hausman's test should be retested to determine whether Fixed Effect or Random Effect Model should be used in panel data regression analysis.

The Hausman test statistic follows the chisquare statistic distribution with the degree of freedom of 3 , thus the value of the chi-square table is 7.81473. Based on the Hausman test result, it is indicated that the Hausman statistic value $>$ chi-square table and at a significance level of 5 percent, the chi-square probability value is significant because $0.0089<0.05$. Therefore, H0

(1) is rejected and H1 is accepted, thus the model chosen for panel data regression in this research uses Fixed Effect Model.

After doing the classical assumption test, it can be concluded that there are symptoms of autocorrelation. According to Gujarati and Porter (2012), if there is an autocorrelation problem, Generalized Least-Square (GLS) method is better than Ordinary Least-Square (OLS) method. With the autocorrelation symptoms, although it will not make the OLS estimators biased, remains consistent, and normally distributed, but the estimators are inefficient. Therefore, before the interpretation on the results and discussion, the statistical test should be conducted in panel data regression using GLS method and Fixed Effect Model. The result of regression test using Fixed Effect Model, with GLS method, is performed using software Eviews 8, is presented in Table 3

Therefore, the regresion equation can be formulated as follows:

$$
\mathrm{EKS}=3.64 \mathrm{E}+10+3.651777 \mathrm{FDI}+1.34 \mathrm{E}+09 \mathrm{COP}-3.77 \mathrm{E}+09 \mathrm{INF}
$$
(0.0000)
(0.0000)
(0.0007) 


\subsection{Discussion}

\subsubsection{The Effect of FDI on Export}

The result of regression estimation with Fixed Effect Model shows that FDI variable has a positive and significant effect on export volume in five countries that is Indonesia, Malaysia, Philippine, Thailand, and Vietnam. The coefficient value of 3.65 indicates that each 1 US dollars increase in FDI that enters a country will increase export volume for 3.65 US dollars. Thus, if the incoming FDI is at 100.000 US dollars then export will increase at 365.000 US dollars.

This result is in accordance with the hypothesis proposed and literature review, which states that FDI has a positive effect on export volume. The increase in FDI will increase the productivity, through the availability of capital (Chiappini, 2011), transfer technology (Blalock and Gertler, 2008) and increased human resources capacity in term of production of export commodities (Haskel, 2007). FDI inflow is also a determinant of exports in BRIC countries (Brazil, Russia Federation, India, China) and this is due to the export orientation of Multinational enterprises (MNEs) (Ranjan and Agrawal, 2011).

\subsubsection{The Effect of Global Oil Price on Export}

The result of panel data regression analysis shows that world oil price (crude oil price) has a positive and significant effect on export volume in five countries. The coefficient value of $1.34 \mathrm{E}+09$ indicates that each increase of 1 US dollars per Barrel in world oil price will increase export volume at 1.34 billion US dollars.

The analysis shows an inconsistency with the hypothesis, which proposed that oil price has a negative effect on export. However, as suggested by the result, the increased of world oil price does not lead to the decreased of export. On the other hand, as the world oil price increase, the export performance of five ASEAN countries are increased.
This may be happen, as in the research conducted by Saher (2011) in India in the year of 1971-2009, using Cointegration and Fully Modified Ordinary Least Squares (FMOLS) methods, he finds that the world oil price has a positive effect on export revenue in the countries. This research reveals that with a strong human resource capital, the increased of oil price will not affect the productivity of goods and services. Moreover, if the human capital can continue to innovate by finding alternative energy sources, thus the pressure in producing goods and services can be resolved.

This research result also supported by the research conducted by Rady et al. (2010) in India, in the year of 2000 to 2010 , which shows that government's policy that remained focused on real production, productivity, and sector shifts (to increase industrial and services revenue) have a positive effect on the effort to overcome the pressure in productivity of goods and services.

Zhang et al in Saher (2011) states that China, which have very good economic growth, can overcome the problems regarding the increased world oil price. The country's large labor force becomes an advantage in facing competition in the international market. Moreover, the increase in world oil price creates big challenges to the China's competitors in exporting goods and services. Thus, a positive relation between world oil price and export can happen in the countries that are able to maintain productivity and have the advance of human resources.

\subsubsection{The Effect of Inflation on Export}

The result on the effect of the inflation on exports volume shows that inflation has a negative and significant effect on export in five ASEAN countries. Inflation variable has a coefficient value at $3.77 \mathrm{E}+09$. This indicates that for each 1 percent increase in inflation level will decrease exports volume of 3.77 billion US dollars. 
The result of hypothesis test support the hypothesis proposed, which states that there is a negative effect of inflation on export volume. The result indicates that continous increase in the overall price of goods will decrease exports. Increased prices will caused a competition between a local product and imported product, which will affect the pricing policy (Kamin and Klau, 2003). Inflation can lead to increase the price of input thereby decreasing the productivity of firms (Dritsakis, 2004; Narayan and Smyth, 2011). Therefore, high cost of production will reduce the competitiveness of a country compared to the other countries (Sinn, 2014).

\subsubsection{The Difference between Countries}

Constant values indicate that there is a difference in term of the effect of independent variables on dependent variables among the sample countries. Constant values from the sample countries is presented in Table 4:

Based on the table above, it can be seen the difference of constant value from each country, and the difference of each country. To be able to interpret the result (as presented in Table 4) the constant value from each country is added with the constant value in data panel regression model that is $3.64 \mathrm{E}+10$. Thus, it can be concluded that in Indonesia, when FDI, world oil prices fluctuation, and inflation is not existent, or if those variables have zero value, the value of Indonesian exports will remain at $4.55 \mathrm{E}+10$ or 45.5 billion US dollars. The constants value for Malaysia and Thailand after being added with constants value on the regression model are $8,51 \mathrm{E}+10$ and $7,82 \mathrm{E}+10$, thus, Malaysia and Thailand exports is valued at 85.1 billion US dollars and 78.2 billion US dollars when there is no FDI, world oil prices fluctuation, and inflation or if those variables have a zero value. Meanwhile, in the Philippines and Vietnam, when the values of those variables are zero, the country's exports are fixed at $-1,97 \mathrm{E}+10$ and $-7 \mathrm{E}+9$ or $-19,7$ billion US dollars and -7 billion US dollars.
Table 4. Constant value of Indonesia, Malaysia, Filipina, Thailand, and Vietnam

\begin{tabular}{lc}
\hline \multicolumn{1}{c}{ Country } & Constant Value \\
\hline Indonesia & $9.07 \mathrm{E}+09$ \\
Malaysia & $4.87 \mathrm{E}+10$ \\
Filipina & $-5.61 \mathrm{E}+10$ \\
Thailand & $4.18 \mathrm{E}+10$ \\
Vietnam & $-4.34 \mathrm{E}+10$ \\
\hline \multicolumn{2}{c}{ Source: Processed, using Eviews 8}
\end{tabular}

\section{Conclusions}

The results of this research indicate that FDI has a positive and significant effect on the exports volume in the five countries. World oil prices have a positive and significant effect in five ASEAN member countries. This conclusion is different from the hypothesis that argues that the export volume will decrease if world oil price increases, because production cost will increase along with the increase of oil price. On the other hand, the result shows that the increase in world oil prices also increase exports volume. This can happen if the country's competitive advantage can be maximized, which includes human resources and productivity improvement, and sector transition policies. Thus, a country can be superior in goods and services trade, when competitors are hampered by rising oil prices. The advantages of human resources are varies such as the capability to create an alternative energy sources that will maintain or improve productivity, as well as an innovation that increases the value of goods and services produced. Inflation has a negative and significant effect on exports. A continuous increase in the overall price of goods will increase production costs. Therefore, the competitiveness of exported goods produced by a country that experiencing a high inflation rate will decrease and its export volume will also decrease.

\section{Recommendations}

The government may seeks for FDI if there is a limited capital for the development productive sectors and increasing the market share of produced goods that intended for both 
the domestic and international market. Simple bureaucracy and increased efficiency will attract foreign investors to invest their fund directly or indirectly. Therefore, the government in a country should be able to convince the investors in order to develop the economics potential owned by a country.

Enhancement of strategic research that aims to develop technology and discovery of alternative fuels, thus productivity can be maintained without being affected by the fuel price fluctuation. Therefore, the production of exportoriented goods will increase, and the productivity of goods will not easily affected by the volatility of fuel prices, which is caused by demand and supply in the commodity market. The discovery of alternative energy and new production technique can increase a country productivity significantly in producing goods or services for both domestic and export-oriented.

Exports and export competitiveness improvement should be done by each country. Inflation control in order to reduce production costs is an effort that requires full integration among government, private parties, and the society, and it is expected to increase the productivity of goods and services. Indonesia, Malaysia, Philippines, Thailand, and Vietnam will face the AEC, thus an improvement in the production of goods and services competitiveness should be performed to compete and develop each countries' economy and to create prosperity in each country.

\section{References}

Blalock, Garrick. and Gertler, Paul J. (2008). Welfare Gains from Foreign Direct Investment through Technology Transfer to Local Suppliers. Journal of International Economics 74: 402-421.

Chiappini, P. (2011). FDI and Trade: A Granger Causality Analysis in a Heterogeneous Panel. Economics Bulletin 31(4): 2975-2985.

Dritsakis, N. 2004. A Causal Relationship between Inflation and Productivity: An
Empirical Approach for Romania. American Journal of Applied Sciences 1: 121-8.

Dritsaki, Chaido, and Melina Dritsaki. (2012). Export and FDI: A Granger Causality Analysis in a Heterogeneous Panel. Economics Bulletin 32 (4): 3128-3139.

Ekmekcioglu, Ercan. (2012). The Macroeconomic Effect of World Crude Oil Price Changes. International Journal of Business and Social Science 3 (6): 268-272.

Gujarati, Damodar N., and Dawn C Porter. 2012. Dasar-dasar Ekonometrika. Jakarta: Salemba Empat.

Haskel, Jonathan. E. (2007). Does Inward Foreign Direct Investment Boost The Productivity of Domestic Firms?. The Review of Economics and Statistics 89 (3): 482-496.

Kabir, Shahriar, and Ruhul A Salim. (2014). Regional Economic Integration in ASEAN. Journal of Southeast Asian Economies 31 (2): 313-335.

Kamin, Steven B. and Klau, Marc. (2003). A Multi-Country Comparison of the Linkages between Inflation and Exchange Rate Competitiveness. International Journal of Finance and Economics 8: 167-184.

Karsalari, Abbas. Rezazadeh., et al. (2013). Export and FDI in Asian Countries: Panel Causality Analysis. Hyperion Economic Journal 1 (2): 60-66.

Lutz, Stefan, and Oleksandr Talavera. (2004). Do Ukrainian Firms Benefit from FDI?. Economics of Planning 32 (2): 77-98.

Narayan, Paresh and Smyth, Russell. (2011). The Effect of Inflation and Real Wages on Productivity: New Evidence from a Panel of G7 Countries. Applied Economics 41: 12851291

Ranjan, Vinit. and Agrawal, Gaurav. (2011). FDI Inflow Determinants in BRIC countries: A Panel Data Analysis. International Business 
Avalaible online at http://journals.ums.ac.id, Permalink/DOI: 10.23917/jep.v19i1.5832

Jurnal Ekonomi Pembangunan: Kajian Masalah Ekonomi dan Pembangunan, 19 (1), 2018, 94-101

Research 4 (4): 255-263.

Pardede, Soy M. (2011). Towards an Economic Community: In South East Asia. International Trade Forum 4: 20-21.

Saher, Noor. (2011). Impact of Oil Prices on Economic Growth and Exports Earning:
In the Case of Pakistan and India. The Romanian Economic Jornal 13 (40): 117-130.

Sinn, Hans-Werner. (2014). Austerity, Growth and Inflation: Remarks on the Eurozone's Unresolved Competitiveness Problem. The World Economy 37 (1): 01-13 